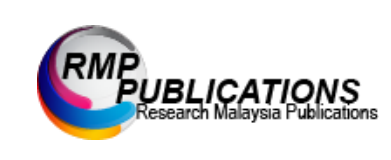

Journal of Social Science and Humanities, 4 (2): 01-05, 2021

e-ISSN: 2600 - 9056

(C) RMP Publications, 2021

DOI: $10.26666 / \mathrm{rmp}$.jssh.2021.2.1

\title{
Internationalism and Global Competences in Foreign Language Teaching
}

\author{
Hind Aljuaid \\ Foreign Languages Department, Taif University
}

\begin{abstract}
Global citizenship education and intercultural citizenship education are critical aspects of foreign language teaching that are anchored on enhancing global competence and awareness of global issues where the learners respect the global culture. The internationalist perspective to foreign language teaching and learning focuses on empowering learners with skills that enable them to tackle global issues in tandem with the spirit of the United Nations Sustainable Development Goals (SDGs). Foreign language education is the platform that could be used to promote global competence that embrace intercultural dialogue and this in turn facilitates the bridging of differences across national, ethnic, and linguistic lines as shared universal values.
\end{abstract}

\section{Keywords: Foreign language teaching and learning, global competence, internationalism, internationalist, global citizenship education, intercultural citizenship education.}

\section{INTRODUCTION}

The Third Summit of Heads of State and Government under the auspices of the Council of Europe (COE) that was held in Warsaw in 2005 concluded that institutions can only work efficaciously when they are premised on a culture of global competence [1]. Education plays a critical role in ensuring the attainment of this overarching goal as it ensures that "young people acquire the knowledge, values and capacity to be responsible citizens in modern, diverse societies" [1] Foreign language teaching and learning as part of education thus plays a critical role in shaping learners through citizen education and empowering them with intercultural competence as well as global competence if the internationalist perspective is taken as this paper outlines.

This paper argues that foreign language teaching (FLT) is by its nature international, but it needs to take an internationalist or cosmopolitan perspective. This means that the teaching and learning of foreign language should be enriched through a myriad of ways which include global citizenship education (GCE), intercultural competence education (ICE) and a focus on the United Nations' (UN) Sustainable Development Goals (SDGs). In this regard, the thrust of foreign language teaching should be to empower learners with global competence, which is "the capacity to examine local, global and intercultural issues, to understand and appreciate the perspectives and worldviews of others, to engage in open, appropriate and effective interactions with people from different cultures, and to act for collective well-being and sustainable development [2]. Furthermore, the paper will demonstrate that foreign language teaching can become a central component of an interdisciplinary approach to intercultural dialogue that ultimately foster respect for cultural diversity. [1].

\section{Foreign Language Teaching}

Foreign language teaching refers to "the teaching of a non-native language outside of the environment where it is commonly spoken" [3]. This implies that a language is deemed to be foreign when it is taught in school but is not spoken in the community where the teaching takes place, and this can be used as a platform to instil a global culture within the learners [4]. The benefits of learning a foreign language are numerous to both the learners and the society at large and these include the ability to communicate efficaciously and creatively and to engage in "real-life situations through the language of the authentic culture itself" [3].

In most countries, foreign languages are taught from elementary level and in some African countries for instance, English is taught as a foreign language at the earliest phase of education especially in sub-Saharan Africa whereas in Central Africa, French is the most common foreign language that is taught in schools [5], [6]. Researchers have unpacked contemporary language learning theories, which include "Universal Grammar, Autonomous Induction, Associative-Cognitive CREED, Skills Acquisition, Input Processing, Processability, Concept-Oriented Approach, Interaction Framework

Corresponding Author: Hind Aljuaid, Foreign Languages Department, Taif University. E-mail: dr.hind@ @u.edu.sa 
and Vygotskian Socio-Cultural Theory" [7]. These approaches are important in ensuring the effectiveness of foreign language teaching and learning and what is necessary is for the educators to use these theories in ensuring that learners acquire the foreign languages and gain the skills that make them global citizens.

Teaching a foreign language, therefore, requires addressing students' expectations, fostering a positive learning environment and striking a balance in the methodologies used, such as grammar-translation, the direct method (natural approach), the audio-lingual method and full immersion [8], [9]. The essence of foreign language teaching and learning was summed up as follows:

Learning another language provides access into a perspective other than one's own, increases the ability to see connections across content areas, and promotes an interdisciplinary perspective while gaining intercultural understandings. Language is the vehicle required for effective human-to-human interactions and yields a better understanding of one's own language and culture. Studying a language provides the learner with the opportunity to gain linguistic and social knowledge and to know when, how, and why to say what to whom [3].

The implication is that foreign language learning is a catalyst for competences for global culture hence language competence is critical in enabling learners to exercise their intercultural competences [1].

\section{Internationalism versus Internationalization}

Byram asked a thought-provoking question when he hypothesized as follows: "Foreign language teaching (FLT) directs learners' attention to other countries and is therefore 'international', but is it 'internationalist'?" [11]. This question can only be answered by unpacking the differences between internationalism and internationalist approaches to foreign language teaching and learning.

Internationalism has been defined as a situation where different countries work together to promote similar causes or interests in a mutually beneficial manner, that is, the advocacy of cooperation and mutual understanding among nations [12]. In most cases, such causes are supported by international organizations that include the United Nations [12], [13]. Another definition of internationalism was given as follows:

What I mean by internationalism is a readiness to act on the assumption that mankind as a whole is the proper society to have in mind for matters that cannot with safety or with such good effect be left exclusively within the domain of smaller social groups such as nations. I think it will be agreed that this is not an extravagant definition [12].

An internationalist perspective in foreign language education has been hailed as the potential panacea to the enrichment of learning as it promotes global citizenship and this entails tackling issues that might be beyond the scope of nations [11], [15]. In this regard, an internationalist perspective empowers learners with "an Archimedean point from which to view the world, and their own nation and country within it, a point from which they can see what they have never seen before" [11]. These 'binoculars' are critical in broadening the horizon for the learners as they are taught to appreciate and respect cultures that are not theirs through enhanced intercultural competence and understanding of global issues in a way that thwarts fundamentalism, radicalisation and other forms of malfeasance and uncouth behaviors [10]. According to Moeller and Catalano:

As classroom tasks become more focused on real-world issues, texts, or events, and problemsolving based tasks, technology introduces a new dimension to the teaching and learning process that incorporates the use of social media such as Facebook, Twitter, Skype, Voice Thread and others Digital media allows students to manipulate learning materials and language at their own pace and according to individual needs [3].

To this end, foreign language teaching that is premised on the internationalist perspective in which the curricula and pedagogy, assessment methodologies and even teacher education that reduce people's susceptibility to radicalization in order to eliminate extremism in the contemporary world is recommended [10]. Inculcating values of global citizenship is critical, and this can be achieved through citizenship education and global citizenship education that makes students responsible citizens.

\section{Citizenship Education \& Global Citizenship Education}

With effect from 2002, citizenship education took center-stage in learning and teaching as most countries included it as a mandatory subject in countries such as England, Australia and the United States of America [16]. Citizenship education is mainly concerned with the promotion of patriotism and nationalism and to inculcate knowledge of national issues, values and ideologies. Citizen education is thus anchored on the nationalism perspective but this paper advocates for a more holistic perspective as expounded below. 
It is worthwhile to note that citizen education has taken a new twist as it has grown into global citizenship education (GCE), which has taken center-stage after the United Nations Education and Scientific Organization (UNESCO) adopted the Global Education First Initiative that was meant to engender global citizenship [13], [17]. The main aim of global citizenship education is "to empower learners to engage and assume active roles both locally and globally to face and resolve global challenges and ultimately to become proactive contributors to a more just, peaceful, tolerant, inclusive, secure and sustainable world" [18].

What this implies is that global citizenship education promotes tolerance, peace-building, social inclusion and sustainability and this internationalist perspective to foreign language teaching and learning is set to revolutionize the world and make it a better place to live [18]. Foreign language teaching and learning can, therefore, take an internationalist approach that teaches learners the capabilities to interact with versatile world issues related that focus on environmental protection and sustainable development in consonance with the United Nations Sustainable Development Goals (SDGs); cross-cultural relationships, and peace building [17].

In Colombia, for instance, it was realized that teaching and learning English using the global citizenship education approach enabled students to develop into responsible citizens who are "more critical about their role in the world, and about how to build empathy and positive relationships with others, which should be one of the ultimate goals of foreign language education" [17]. In the same vein, in Japan, several English teachers and educators at tertiary institutions are taking an active role in addressing world issues in their classes and this has led to the formation and growth of the Global Issues in Language Education (GILE) as an interest group within the Japan Association of Language Teachers [16]. This internationalist approach enables students to appreciate and "reflect upon how such problems as environmental degradation, poverty impact on the lives of individuals... [which in turn] can evoke feelings of solidarity, and as they become more conscious of the interconnectedness of issues, students are encouraged to consider how aspects of their own day-to-day activity can have far-reaching, and even global consequences" [16].

The approach that Japan takes in its foreign language teaching and learning acknowledges the quintessential role that language plays as the medium though which efficacious human-to-human interfaces occur and enables one to gain knowledge of different cultures [3].

As Byram pointed out, global citizenship education focuses on imparting the following skills in learners: social and moral responsibility; community involvement; and political literacy [11]. In addition to these three important areas, "Global citizenship implies not only a commitment to the values of peace and justice enshrined in the Universal Declaration of Human Rights, but also a respect for diversity, and an ability to engage with people who are 'all equal, all different' [16].

Foreign language teaching and learning can thus be used to nurture intercultural competence, which is the ability to embrace differences, and this can be achieved by embedding citizenship education in foreign language teaching and learning in a concept called intercultural citizenship education' (ICE) [14].

Intercultural citizenship education enhances learning as it goes beyond the nationalism of most citizenship education hence foreign language education that nurtures intercultural communicative competence focuses on critical cultural awareness; understanding other cultures; and an ability to compare one's situation with that of others [19]. Byram et al. thus advocate for an integrated internationalist approach, where language education and citizenship education combine "the relational (focus on 'others'), transnational and critical perspectives of foreign language education with the civic action in the community component of citizenship education" [19], [14]. Competences for global culture in foreign language teaching and learning can be enhanced though cross-cultural citizenship education as follows:

Intercultural citizenship education acknowledges the instrumental value of learning one or more languages but crucially focuses on its educational worth and potential. It is a development in which the role of foreign language education in citizenship and political and moral education is seen as an extension of the scope of citizenship education. Education for citizenship is a development from traditions of 'civic education' [14].

This implies that the combination of citizenship and foreign language education promotes the internationalist (or cosmopolitan) perspective through the emphasis on "the reality of complex and multiple identities and allows a space for the exploration of identity in the context of citizenship" [14]. Educators can thus embed components of the intercultural communicative competence model in their lessons to impart intercultural knowledge and other vital skills that promote assimilation, integration, inclusion and connection [15].

The global competence that arises from an internationalist perspective to foreign language teaching and learning enables learners to critically examine local, global and intercultural issues; to appreciate and comprehend the perspectives and world views of others; and to be able to take part in open, relevant and efficacious interactions with people from different cultures [2]. Furthermore, global competence enables 
learners of foreign language to take appropriate action that improves the well-being of humankind and supports sustainable development [2].

Global competence also plays other roles (as illustrated in Figure 1 below), such as fostering harmonious relationships and supporting the 17 Sustainable Development Goals, which include eradication of poverty and hunger; promotion of lifelong learning and quality education; reduction of inequalities; and promotion of peace, justice and strong institutions [2].

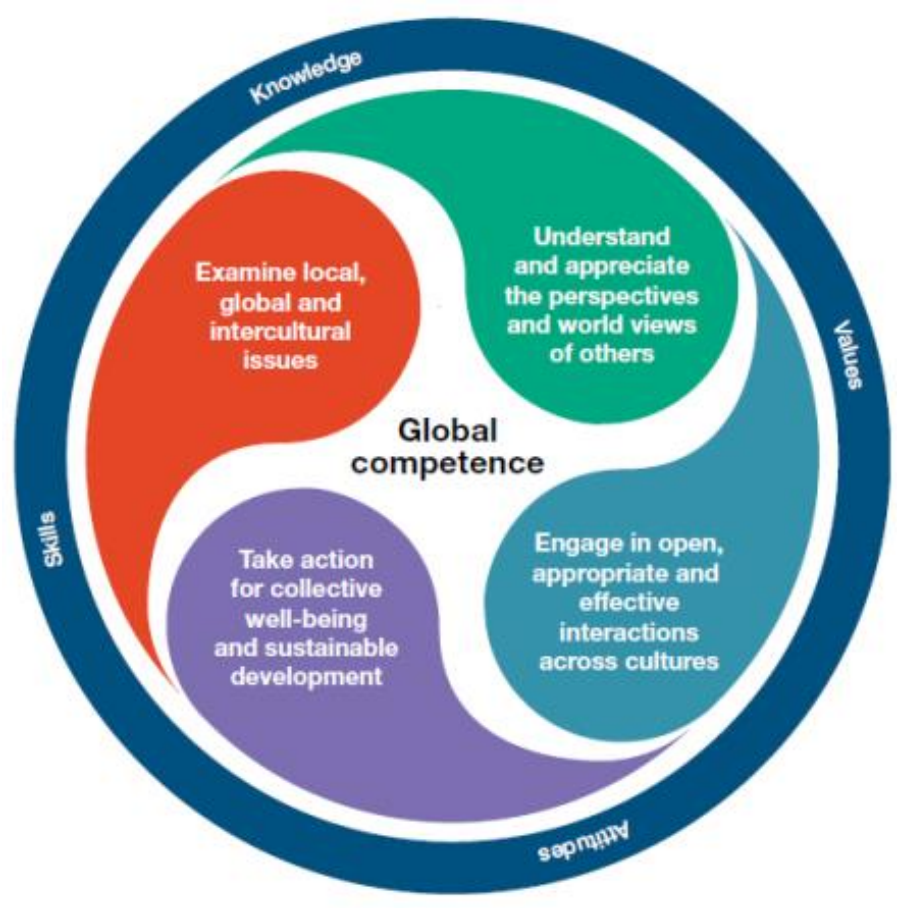

Figure 1: Elements of Global Competence. Source: OECD (2017)

\section{Conclusion}

This paper has demonstrated that foreign language can be used as a mechanism to promote global competence. This can be achieved by adopting global citizenship education ad intercultural citizenship education as part of the internationalist perspective that seeks to develop learners who are globally competent and possess intercultural competence. The paper has further argued that although education in general and foreign language teaching and learning in particular are international in scope, there is need for broadening the scope of language learning to make it internationalist in scope so that the global culture is cultivated in learners.

In conclusion, foreign language teaching and learning should embrace the Sustainable Development Goals that seek, among other things, to eradicate poverty and promote lifelong learning and make learners responsible citizens who embody justice, democracy, and anti-radicalization. The SDGs cover a wide spectrum of areas such as justice, equality, decent work and income, attention to climate change, infrastructure development and quality education, among others. The attainment of these Sustainable Development Goals can be accelerated if foreign language teaching and learning is pillared on the internationalist perspective to enlighten the learners so that they see the world in a different way and appreciate that cultural diversity should be tolerated to create the global village that the internet and social media have created.

\section{REFERENCES}

[1] Council of Europe. (2018). Reference Framework of Competences for Democratic Culture. Strasbourg Cedex: Council of Europe Publishing.

[2] Organization for Economic Cooperation \& Development. (2017). PISA 2018 Global

Competence. Retrieved from https://www.oecd.org/pisa/pisa-2018-globalcompetence.htm/

[3] Moeller, A. \& Catalano, T. (2015). Foreign language teaching and learning. In: Wright, J. D., International Encyclopedia for Social \& Behavioral Sciences, 2nd ed. Elsevier.

[4] Bergwall, I. (2016). Democracy, Culture and Language Teaching: A Study on the Promotion of Cultural Awareness and Democratic Values in the 
Swedish English Language Classroom. Örebro University.

[5] Chan, W. M., Chin, K. N., Nagami, M. \& Suthiwan, T. (2011). Media in foreign language

teaching and learning. In: Chan, W. M., Chin, K. N., Nagami, M. \& Suthiwan, T. [eds.], Studies in Second and Foreign Language Education [SSFLE]. De Gruyter Mouton. Retrieved from https://doi.org/10.1515/9781614510208/

[6] Wong, L. T. \& Dubey-Jhaveri, A. (2015). English language education in a global world:

Practices, issues and challenges. Nova Science. doi: 10.13140/RG.2.1.4479.1129

[7] VanPatten, B. \& Williams, J. [Eds.] (2008). Theories in second language acquisition: An

introduction. New York, NY: Routledge, Taylor \& Francis.

[8] University of Washington. (2021). Center for Teaching and Learning. Retrieved from

https://teaching.washington.edu/topics/just-fortas/teaching-foreign-languages/

[9] Ludwig, J. (2021). The key to foreign language teaching methodologies and how to choose the best for you. Enux Education Limited. Retrieved from https://www.fluentu.com/blog/educator/foreignlanguage-teaching-methodology/

[10] Barrett, M. (2020). The Council of Europe's Reference Framework of Competences for

Democratic Culture: Policy context, content and impact. London Review of Education 18 (1): 1-17.
Retrieved

from https://doi.org/10.18546/LRE.18.1.01

[11] Byram, M. (2018). An essay on internationalism in foreign language education. Intercultural Communication Education 1(2), 64-82.

[12] Elvin, H. L. (1960). Nationalism and internationalism in education. The School Review, 68 (1) $1-22$.

[13] United Nations Development Program. (n.d.). Sustainable Development Goals. New York: UNDP.

[14] Porto, M., Houghton, S. A., \& Byram, M. (2017). Intercultural citizenship in the (foreign) language classroom. Language Teaching Research, 1-15.

[15] Rader, D. (2020). Intercultural understanding: Compelling pedagogy for meeting the 2030 SDGs. Teaching \& Learning for Intercultural Understanding 4, 2020.

[16] Hosack, I. (2011). Foreign language teaching for global citizenship.

[17] Díaz, L. C. (2017). Citizenship education and the EFL Standards: A critical reflection. doi: http://dx.doi.org/10.15446/profile.v19n1.55676

[18] United Nations Education and Scientific Organization. (2013). Global citizenship education: An emerging perspective. Paris: UNESCO.

[19] Byram, M., Golubeva, I. Han, H., \& Wagner, M. (Eds.) (2017). From principles to practice in education for intercultural citizenship. Bristol: Multilingual Matters. 